Bull. Chem. Soc. Ethiop. 2020, 34(3), 523-532.

ISSN 1011-3924

(C) 2020 Chemical Society of Ethiopia and The Authors

Printed in Ethiopia

DOI: https://dx.doi.org/10.4314/bcse.v34i3.8

\title{
SYNTHESIS, CHARACTERIZATION, STRUCTURE DETERMINATION FROM POWDER X-RAY DIFFRACTION DATA, AND BIOLOGICAL ACTIVITY OF AZO DYE OF 3-AMINOPYRIDINE AND ITS COMPLEXES OF Ni(II) AND Cu(II)
}

\author{
Hasan Shamran Mohammed
}

Department of Chemistry, Science College, Al-Qadisiyah University, Al-Qadisiyah, Iraq

(Received January 25, 2020; Revised December 14, 2020; Accepted December 15, 2020)

\begin{abstract}
In the present work azo dye ligand of 3-aminopyridine (L) and its complexes of $\mathrm{Ni}^{\mathrm{II}}$ and $\mathrm{Cu}^{\mathrm{II}}$ were synthesized, characterized and evaluated for antibacterial and antifungal activities in vitro. The L ligand was synthesized by reacting diazonium ion of 3-aminopyridine with 1-naphthole in presence of sodium acetate. The ligand (L) and its complexes were characterized by elemental analysis (CHN), magnetic susceptibility, molar conductivity, UV-Vis spectra, and infrared technique. The (L) azo dye exhibited high sensing for the pH changes. The color of $\mathrm{L}$ dye changed from red in basic medium to yellow color in acidic medium. The data of CHN, UV$\mathrm{Vis}$ and magnetic susceptibility indicate that the complexes $\left[\mathrm{Ni}(\mathrm{L})_{2} \mathrm{Cl}_{2}\right]$ and $\left[\mathrm{Cu}(\mathrm{L})_{2} \mathrm{Cl}_{2}\right]$ are tetrahedral. The complexes of $\mathrm{Ni}(\mathrm{II})$ and $\mathrm{Cu}(\mathrm{II})$ exhibited potent activity against growth of Staphylococcus aureus and Escherichia Coli as well as against Penicillium Sp. And Aspergillus niger. Under visible irradiation (395 $\mathrm{nm}$ ), the (L) azo dye of pyridine exhibited a significant change in the spectra under irradiation.
\end{abstract}

KEY WORDS: Pyridine, Photoisomerization, Pyridylazo, Biological activity, pH sensor

\section{INTRODUCTION}

Azo dyes are an important class of organic chemicals containing at least one azo chromophore $(-\mathrm{N}=\mathrm{N}-)$ which donors the color for this famous type of dyes [1]. They play essential role in academic and applied research [2]. Electronic and geometrical features of azo metal dyes induce redox, nonlinear optical and magnetic properties and these properties lead to increase the sensitivity and stability of these compounds towards optical data storage device $[3,4]$.

Azo dyes consider significant analytical reagents for the micro-estimation of metal ions. 1(2-Pyridylazo)-2-naphthol considers well-known azo dye with term PAN which forms stable complexes with many metal elements [2]. In the same time, it is sensitive for trace concentration of metal elements and trace elements [5,6]. This kind of complexes is highly colored therefore some of them used as dyes and pigments which leads to use it as inkjet printing and toner.

The azo dyes can be exhibited trans and cis isomers depending on the present $-\mathrm{N}=\mathrm{N}-$ chromophore and these dyes can exhibit the photoisomerization process in their complexes [7]. The inter-conversion between the isomers can be achieved photo-chemically and it is possible thermally or electrochemically [8]. Trans isomer is more stable than cis isomer [9]. Azo dye ligands such as aryl azophenols have low-lying $\mathrm{p}^{*}$-orbitals which lead to stabilize the low valence metal redox state in their complexes by increasing chance of charge transfer transition of metal-to-ligand [10].

Cytotoxic studies of azo dye complexes against T47D, MTLn3 and RAW tumor cell lines exhibited a satisfactory inhibitory effect on cells comparable to that of cisplatin [10]. Synthesized complexes of $\mathrm{Mn}^{\mathrm{II}}, \mathrm{Co}^{\mathrm{II}}, \mathrm{Ni}^{\mathrm{II}}$ and $\mathrm{Cu}^{\mathrm{II}}$ of azo dye(1-[(5-mercapto- $1 H-1,2,4$-triazole3-yl)diazenyl]naphthalene-2-ol) exhibited attractive biological activity against many types of bacterial and fungal strains as Staphylococcus aureus, Escherichia coli, Candida albicans and Aspergillus flavus, and antitumor activity toward HEPG2 cell line [11]. 3-Aminopyridine derivatives exhibited antineoplastic activity in vivo toward the L1210 leukemia [12]. Pyridine

*Corresponding author. E-mail: hasan.sh.mohemmed@qu.edu.iq

This work is licensed under the Creative Commons Attribution 4.0 International License 
ring is appear in plenty of natural products such as vitamin B6, niacins, nicotinamide adenine dinucleotide (NAD) and trigonelline [13]. Pyridine is a lot used in pesticides and drugs production because of its attractive properties such as basicity, water solubility, stability, hydrogen bond forming ability beside its small molecular [14].

The drugs of pyridine such as sulfapyridine and salazosulfapyridine used as antiviral, antimicrobial, antioxidant as well as anti-malarial agents [15]. Sulfasalazine is azo dye of pyridine which called under the trade name Azulfidine in pharmacy. It widely employed for treatment of rheumatoid arthritis, Crohn's disease and ulcerative colitis [16, 17]. Therefore, we hereby report to synthesis and characterization of azo dye of 3-aminopyridine and its synthesizing complexes of $\mathrm{Ni}^{\mathrm{II}}$ and $\mathrm{Cu}^{\mathrm{II}}$ as well as screening their biological activity against number of pathogenic bacteria and fungi.

\section{EXPERIMENTAL}

\section{Materials and methods}

The solvents and materials were used without further purification. Sodium nitrite, 3aminopyridine, hydrochloric acid, 1-naphthol, sodium acetate were got from Sigma-Aldrich. $\mathrm{NiCl}_{2} \cdot 6 \mathrm{H}_{2} \mathrm{O}$ and $\mathrm{CuCl}_{2} \cdot 2 \mathrm{H}_{2} \mathrm{O}$ were got from Alfa Aesar.

The UV-Vis spectra of the synthesized compounds were done by using UV-1650 PC UVVisible Spectrophotometer from Shimadzu. The infrared spectra of synthesized compounds were done by using Shimadzu FT-IR 8400S spectrophotometer. ${ }^{1} \mathrm{HNMR}$ spectrum of (L) ligand was done by using Bruker $400 \mathrm{MHz}$ spectrophotometer in DMSO-d6. Mass spectrum of (L) ligand was done by Shimadzu Agilent Technologies 5973C. The elemental analysis (CHN) of the L ligand and its synthesized complexes of $\mathrm{Ni}^{\mathrm{iI}}$ and $\mathrm{Cu}^{\mathrm{II}}$ were done by using EURO EA 3000. The magnetic susceptibility was done by balance magnetic susceptibility model-MSB auto. The molar conductivity measurements for complexes of $\mathrm{Ni}^{\mathrm{II}}$ and $\mathrm{Cu}^{\mathrm{II}}$ were done by using Cond 720 (WTW) in DMSO solvent at room temperature. X-ray diffraction measurements were done by using Bestic Germany Aluminum for (L) ligand.

Synthesis of azo dye of 3-aminopyridine (L)

3-Aminopyridine (0.94 g, $0.0099 \mathrm{~mol})$ was dissolved in $40 \mathrm{~mL}$ of distilled water. $5 \mathrm{~mL}$ of concentrated hydrochloric acid was added to solution of 3-aminopyridine, then the solution was cooled at $0{ }^{\circ} \mathrm{C} .5 \mathrm{~mL}$ aqueous solution sodium nitrite $(0.683 \mathrm{~g}, 0.0099 \mathrm{~mol})$ was cooled to $0{ }^{\circ} \mathrm{C}$. The cold aqueous solution of sodium nitrite was added gradually to cold the acidic solution of 3 aminopyridine to form diazonium salt of pyridine. The diazonium salt of pyridine was let under stirring for $30 \mathrm{~min}$ at $0{ }^{\circ} \mathrm{C}$. Sodium acetate $(2 \mathrm{~g}, 0.02 \mathrm{~mol})$ was dissolved in $8 \mathrm{~mL}$ of distilled water then the solution of sodium acetate was added to $30 \mathrm{~mL}$ ethanolic solution of 1-naphthol $(1.427 \mathrm{~g}, 0.0099 \mathrm{~mol})$. The basic solution of 1-naphthol was put under cooling at $0{ }^{\circ} \mathrm{C}$. The solution of diazonium salt was added gradually to basic solution of 1-naphthol under cooling. The new solution of azo dye of 3-aminopyridine was red and the solution was let overnight. The solution of dye was filtrated and it washed many times with water to remove the salts. It was red powder with yield 90\%. ${ }^{1} \mathrm{H}$ NMR (ppm in DMSO-d6): $11.31(1 \mathrm{H}, \mathrm{s}), 9.169(1 \mathrm{H}, \mathrm{s}), 8.92(1 \mathrm{H}$, $6.5 \mathrm{~Hz}, \mathrm{~d}), 8.70(1 \mathrm{H}, 2.4 \mathrm{~Hz}, \mathrm{~d}), 8.27(2 \mathrm{H}, 9.4 \mathrm{~Hz}, \mathrm{~d}), 7.93(1 \mathrm{H}, 6.4 \mathrm{~Hz}, \mathrm{~d}), 7.24(1 \mathrm{H}, 11.2$ and 5.6 $\mathrm{Hz}, \mathrm{t}), 7.61(2 \mathrm{H}, 5.2 \mathrm{~Hz}, \mathrm{~d}), 7.05(1 \mathrm{H}, 6.8 \mathrm{~Hz}, \mathrm{~d}) . \mathrm{C}_{15} \mathrm{H}_{11} \mathrm{~N}_{3} \mathrm{O} \mathrm{C}: 72.20, \mathrm{H}: 4.41, \mathrm{~N}: 16.85$; experimental: C: $72.05, \mathrm{H}: 4.30, \mathrm{~N}: 16.81$.

Synthesis of $\mathrm{Ni}^{\text {II }}$ and $\mathrm{Cu}^{I I}$ complexes of (L) azo dye ligand

$N i^{I I}$ complex. $(0.249 \mathrm{~g}, 0.001 \mathrm{~mol})$ of (L) ligand was dissolved in $20 \mathrm{~mL}$ of ethanol under heating to $60{ }^{\circ} \mathrm{C}$. Nickel chloride $(0.12 \mathrm{~g}, 0.0005 \mathrm{~mol})$ was dissolved in $10 \mathrm{~mL}$ of buffer solution 
$(\mathrm{pH}=8)$. The solution of $(\mathrm{L})$ ligand was added to hot solution of nickel chloride. The reaction mixture was refluxed under $60{ }^{\circ} \mathrm{C}$ for three hours. The solution of reaction was filtrated, washed by distilled water many times, red powder was put in desiccators to dry. The yield of nickel(II) complex was $60 \%$. Theoretical $\mathrm{C}_{30} \mathrm{H}_{22} \mathrm{~N}_{6} \mathrm{O}_{2} \mathrm{NiCl}_{2}$, C: $57.36, \mathrm{H}: 3.53$, N: 13.38., experimental: C: 57.25, H: 3.42, N: 13.31 .

$C u^{I I}$ complex. We used the same procedure of nickel(II) complex to synthesise $\mathrm{Cu}^{\text {II }}$ complex excepting we used $(0.15 \mathrm{~g}, 0.0005 \mathrm{~mol})$ of cupper(II) chloride. $\mathrm{C}_{30} \mathrm{H}_{22} \mathrm{~N}_{6} \mathrm{O}_{2} \mathrm{CuCl}_{2}$ C: $56.92, \mathrm{H}$ : 3.50, N: 13.28., experimental: C: 56.83, H: 3.33, N: 13.17 .

\section{Biological activity}

The antimicrobial activity of (L) ligand and its synthesizing complexes of $\mathrm{Ni}^{\mathrm{II}}$ and $\mathrm{Cu}^{\mathrm{II}}$ were examined against two types of pathogenic bacteria (Eschershia coli and Staphylococcus aureus) and two types of fungi (Penicillium Sp. and Aspergillus niger) by using agar well diffusion method. Here we used Mueller-Hinton agar for bacterial strains and sabouraud dextrose agar for fungal strains. The autoclaved molten media $(20 \mathrm{~mL})$ was poured in each $90 \mathrm{~mm}$ sterilized Petri plate and allowed to solidify. Three circular well of diameter $6 \mathrm{~mm}$ were made in each Petri dish by using cork borer and each well was filled with $0.1 \mathrm{~mL}$ of the test solution at three different concentrations $50,75,100 \mathrm{mg} / \mathrm{mL}$ for $(\mathrm{L})$ ligand, $\mathrm{Ni}^{\mathrm{II}}$ and $\mathrm{Cu}^{\mathrm{II}}$ complexes and inhibition zones were measured in $\mathrm{mm}$ after $24 \mathrm{~h}$ of incubation period.

\section{RESULTS AND DISCUSSION}

The azo dye ligand 4-(3-pyridyl azo)- $\alpha$-naphthol of 3-aminopyridine (L) was synthesized by coupling $\alpha$-naphthol with diazonium ion of 3 -aminopyridine in present of sodium acetate as shown in Scheme 1. The yield of synthesized dye (L) was $90 \%$ with red powder.

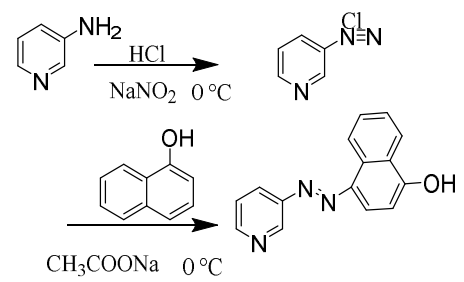

Scheme 1. Coupling reaction of $\alpha$-naphthol with diazonium ion of 3-aminopyridine.

The mass spectrum is consistent with the existence of $m+$ of the (L) dye (Figure 1) which is in agreement with elemental analysis $(\mathrm{CHN})$ of the $(\mathrm{L})$ dye.

Test of $\mathrm{pH}$ sensing effect on (L) ligand was evaluate by UV-Visible spectra in basic and acidic mediums in acetone at $10^{-5}$ molarity at room temperature which are depicted in Figure 3. The synthesized dye (L) exhibited decreasing in intensity of $\pi-\pi^{*}$ transition at $\mathrm{pH}=10$ compared to parent azo and arising a new band at $550 \mathrm{~nm}$ which is due to ICT from OH (donor) to pyridine ring (accepter) during the azo functional (bridge) that meaning that the electronic transition involves the overall electronic system of the azo dye (L) ligand [19]. The spectrum of hydrazone form of (L) dye at $\mathrm{pH}=2$ appears little bit red shift and increasing in intensity for $\pi$ $\pi^{*}$ transition compared to parent azo form which is in agreement with the literatures [20-23]. These dramatic changes candidates this ligand a good example on the analytical indicators of acid-base like methyl orange which is azo dye. 


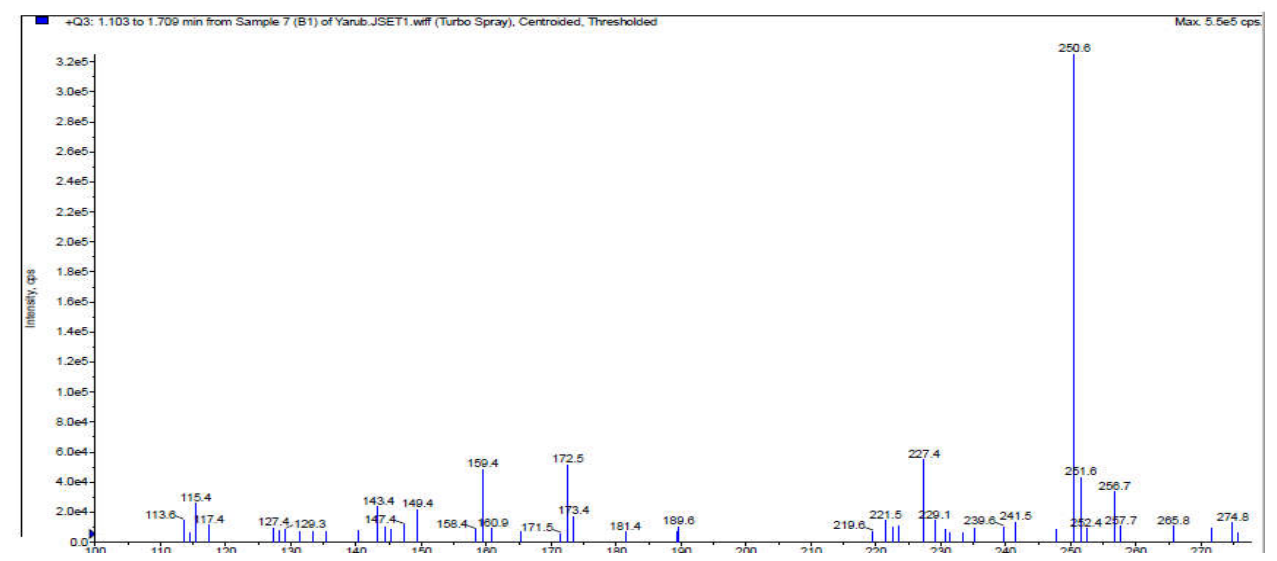

Figure 1. Mass spectrum of azo dye ligand of 3-aminopyridine (L).

The geometry optimization of (L) dye was done by DFT using (Gaussian 09, B3LYP functional) with (LanL2DZ) basis set [18] which is depicted in Figure 2.

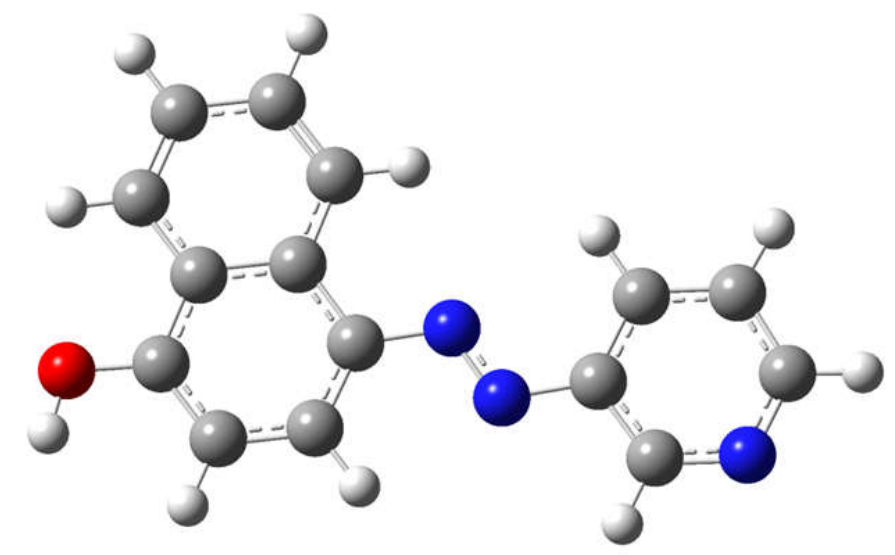

Figure 2. Optimization structure of (L) ligand using B3LYP functional with (LanL2DZ) basis set.

Beside to use photoisomerization of azo dyes for high optic data storage, recently this process gets large attention and applications in biological system [24]. For that, we are interested in controlling the photoisomerization of our ligand (L) which exhibited interesting absorbance in visible region. We evaluate the photochromic changes of (L) dye by UV-Visible spectra in acetone before irradiation, under irradiation and after irradiation at room temperature (Figure 4). The UV-Vis spectrum of (L) dye before irradiation presents trans isomer which is a planer and stable more than cis isomer which exhibits under irradiation. The intensity of $\pi \rightarrow \pi^{*}$ of (L) dye exhibited low intensity under irradiation with light of $395 \mathrm{~nm}$ for 3 min while under 7 min of irradiation, the intensity of $\pi \rightarrow \pi^{*}$ gone more down and appearing a new band at 650 $\mathrm{nm}$ having low intensity which is due to $n \rightarrow \pi^{*}[25,26]$. The last transition is more allowed in cis isomer than trans isomer which is planer. When we remove the source of light, the spectrum 
of cis isomer vanished with time and we got same spectrum of trans isomer. Which means that the (L) azo dye possess real photochromic behavior [27] and a good candidates for optical data storage devices.
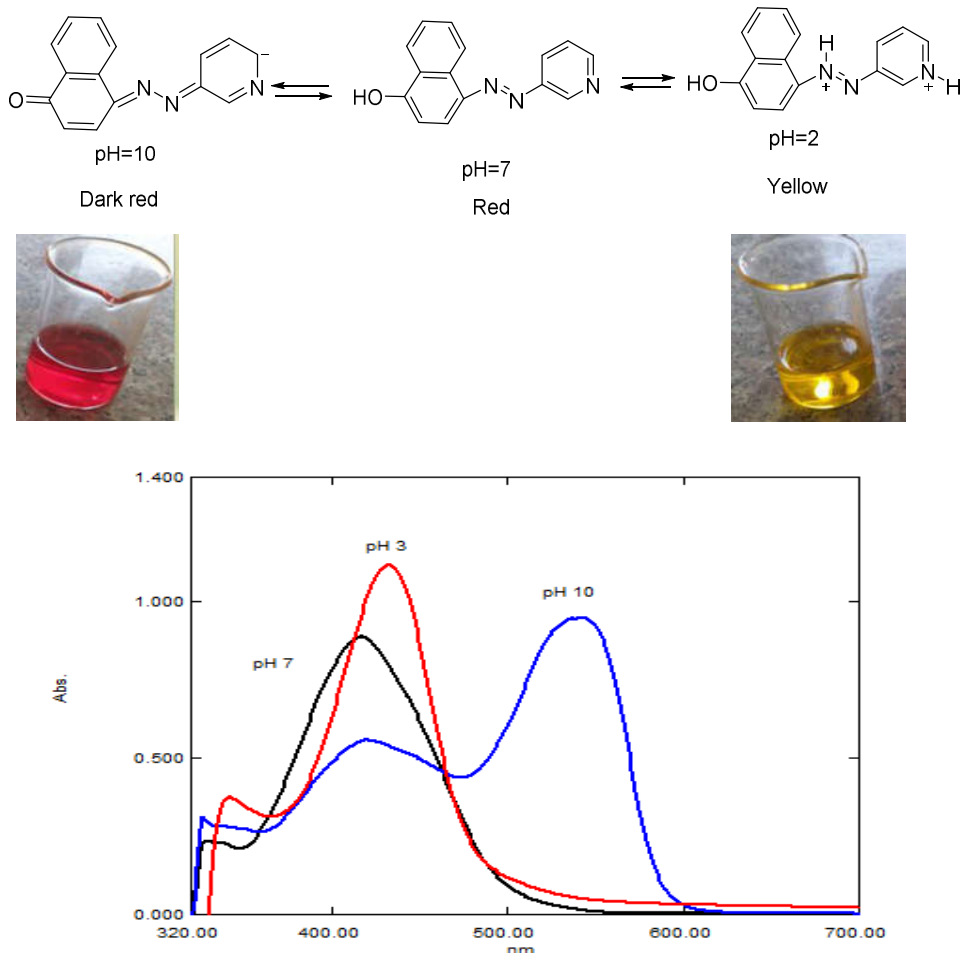

Figure 3. UV-Vis spectra of ligand (L) in basic, neutral and acidic media.

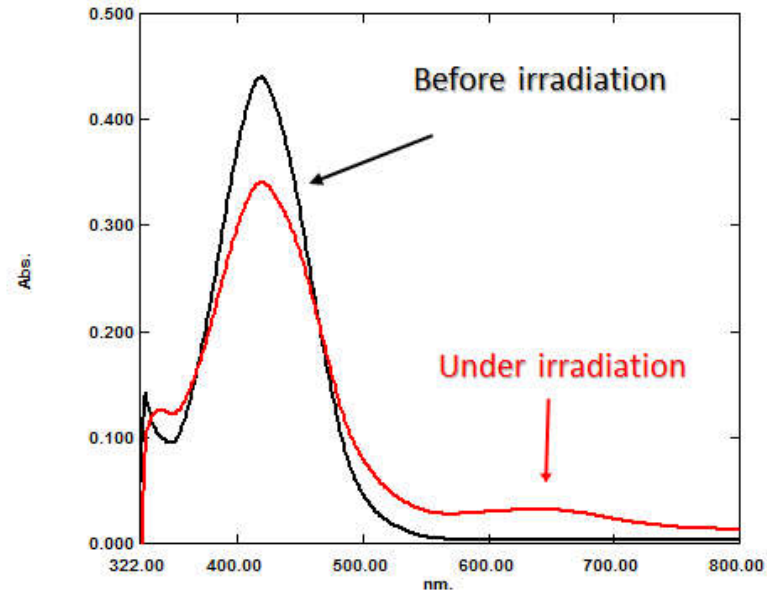

Figure 4. Evaluation of photochromic behavior of (L) dye under irradiation at $395 \mathrm{~nm}$ at $25{ }^{\circ} \mathrm{C}$ in acetone.

Bull. Chem. Soc. Ethiop. 2020, 34(3) 
$X$-ray diffraction of powder

The X-ray pattern of synthesized azo dye ligand (L) has been presented by using software Materials Studio. We have done the simulated XRD pattern of azo dye with its experimental XRD pattern. The result was perfect match between them which are depicted in Figure 5. The unit cell of (L) azo dye is monoclinic and the data of unit cell is depicted in Table 1.

Table 1. Cell data and crystal parameter of (L) azo dye.

\begin{tabular}{|l|l|}
\hline Space group & P-1 \\
\hline Crystal system & Triclinic \\
\hline a $(\AA)$ & 7.4343 \\
\hline b $(\AA)$ & 8.3073 \\
\hline c $(\AA)$ & 22.4717 \\
\hline Alpha & 79.8675 \\
\hline Beta & 94.8902 \\
\hline Gamma & 65.2226 \\
\hline Wavelength $(\mathrm{Cu} \mathrm{Ka})(\AA)$ & 0.71073 \\
\hline
\end{tabular}

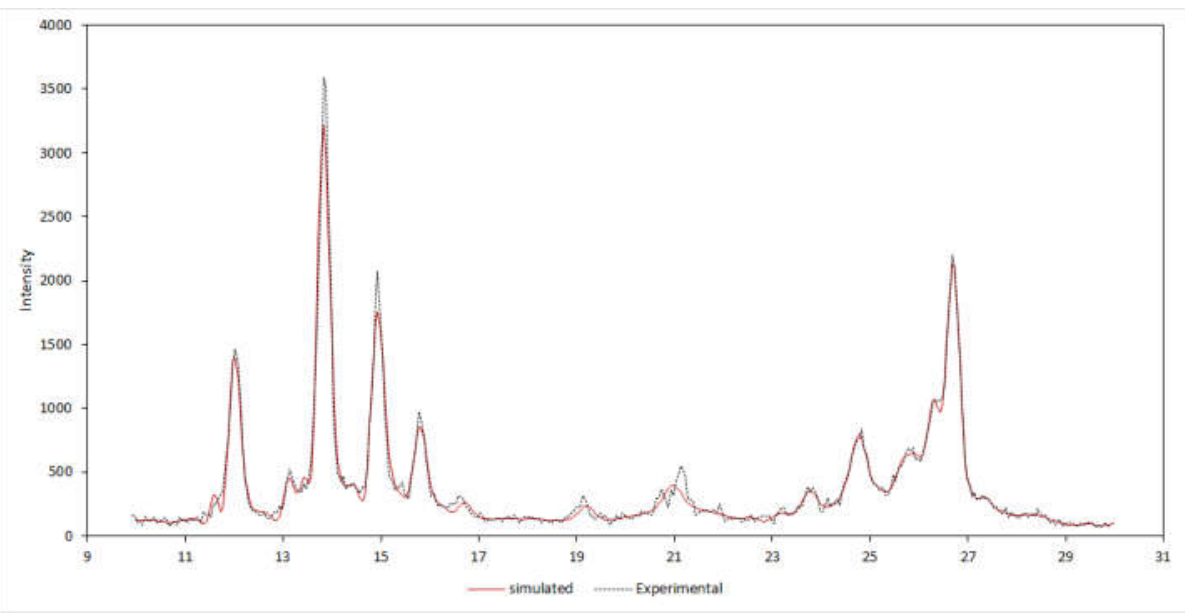

Figure 5. The X-ray diffraction patterns of experimental and simulated of synthesized azo dye (L) of 3-aminopyridine.

The complexes of $\mathrm{Ni}^{\mathrm{II}}$ and $\mathrm{Cu}^{\mathrm{II}}$ were synthesized in same procedure by mixing nickel(II) chloride or copper(II) chloride with (L) ligand at $\mathrm{pH}=8$ under $60{ }^{\circ} \mathrm{C}$ for $3 \mathrm{~h}$. The synthesized complexes were characterized by $\mathrm{CHN}$ analysis elements, molar conductivity, magnetic susceptibility, UV-VIS and infrared spectra. Molar conductivity of $\mathrm{Ni}^{\mathrm{II}}$ and $\mathrm{Cu}^{\mathrm{II}}$ were 6 and $10{\mathrm{~S} . \mathrm{cm}^{2}}^{2} \cdot \mathrm{mol}^{-1}$, respectively, that means that the complexes are nonelectrolytes. The mole ratio for both complexes was 2:1 ligand:metal (Scheme 2).

The infrared spectrum of the azo dye ligand (L) showed important characteristics peaks in the range of $4000-400 \mathrm{~cm}^{-1}$ such as $\mathrm{OH}\left(3200 \mathrm{~cm}^{-1}\right), \mathrm{CH}\left(3050 \mathrm{~cm}^{-1}\right), \mathrm{C}=\mathrm{N}\left(1580 \mathrm{~cm}^{-1}\right), \mathrm{N}=\mathrm{N}$ $\left(1505 \mathrm{~cm}^{-1}\right), \mathrm{C}=\mathrm{C}\left(1403 \mathrm{~cm}^{-1}\right), \mathrm{O}-\mathrm{H}$ bend $\left(1390 \mathrm{~cm}^{-1}\right), \mathrm{C}-\mathrm{O}\left(1290 \mathrm{~cm}^{-1}\right), \mathrm{CH}$ bend $(1080,700$ $\left.\mathrm{cm}^{-1}\right) . \mathrm{Ni}^{\mathrm{II}}$ and $\mathrm{Cu}^{\mathrm{II}}$ complexes exhibited infrared spectra similar to the free ligand (L) excepting the $\mathrm{C}=\mathrm{N}$ functional undergo red shift $23-34 \mathrm{~cm}^{-1}$, respectively $[28,29]$. 


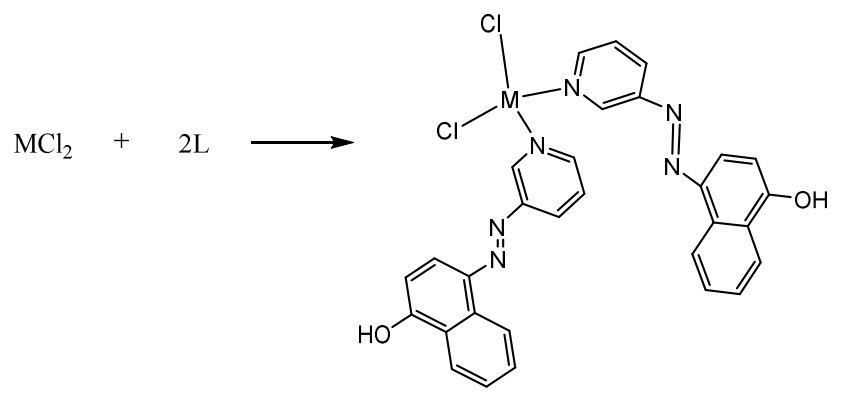

Scheme 2. Synthesis of $\mathrm{Ni}^{\mathrm{II}}$ and $\mathrm{Cu}^{\mathrm{II}}$ complexes.

Electronic spectra of azo dye ligand $(L)$ and its synthesized complexes

In general, azo dye ligands exhibit strong $\pi-\pi^{*}$ and weak $n-\pi^{*}$ bands, but in our case the azo dye (L) exhibits $\pi-\pi^{*}$ overlaps with $n-\pi^{*}$ to form large and strong band in visible region at $420 \mathrm{~nm}$ because there is donor group $(\mathrm{OH})$ and acceptor functional pyridine ring which leads to overlap $\pi-\pi *$ transition with $n-\pi *$ transition [19].

Nickel(II) complex exhibited 10820 and $15215 \mathrm{~cm}^{-1}$, which are due to ${ }^{3} \mathrm{~T}_{1}(\mathrm{~F}) \rightarrow{ }^{3} \mathrm{~A}_{2}(\mathrm{~F})$ and ${ }^{3} \mathrm{~T}_{1}(\mathrm{~F}) \rightarrow{ }^{3} \mathrm{~T}_{1}(\mathrm{P})$, respectively, with magnetic susceptibility equal to 2.81 B.M., which is in agreement with tetrahedral configuration $[29,30]$. On the other hand, the strength of chloro and azo dye ligands are low to mediumdepending on the spectrochemical series therefore the complex prefers the tetrahedral than square planer configuration.

Copper(II) complex exhibited charge transfer at $21276 \mathrm{~cm}^{-1}$, and d-d transition due to ${ }^{2} \mathrm{~T}_{2}(\mathrm{D}) \rightarrow^{2} \mathrm{E}(\mathrm{D})$ at $12468 \mathrm{~cm}^{-1}$ beside the electronic transition $\pi \rightarrow \pi^{*}$ of (L) ligand with magnetic susceptibility equal to 1.92 B.M., which is in agreement with tetrahedral configuration $[30,31]$.

\section{Biological activity}

The global emergence of antimicrobial resistance is increasingly decreases the effectiveness of many antibiotics, especially in immune-compromised patients. Drug resistance, especially by bacteria and fungi, is consider one of the major concerns to public health and scientific communities' worldwide [32]. Many azo dye complexes consider important biological species [33]. In our study we investigated the biological activity of our synthesized compounds against two types of bacteria gram positive bacteria (S. aureus) and gram negative bacteria $(E$. Coli) and two types of fungi (Aspergillus niger and Penicillium Sp.) by agar well diffusion method. The results depicted in Table 2, revealed that the $\mathrm{Ni}^{\mathrm{II}}$ and $\mathrm{Cu}^{\mathrm{II}}$ complexes exhibited interestingly high inhibition zone against tested $E$ coli and $S$. aureus while the (L) ligand did not show interesting antibacterial activity against screened strains and moderate activity against fungal strains. This activity may be attributed to our complexes are amphiphilic nature which may facilitate the penetration through the bacterial cell membranes which is rich in polysaccharide fraction and also passes through the cell walls of fungi $[34,35]$. The $\mathrm{Ni}^{\mathrm{II}}$ complex exhibited higher inhibition zone against $E$. coli than $S$. aureus. The $\mathrm{Cu}^{\mathrm{II}}$ complex exhibited high inhibition against $E$. coli and $S$. aureus.

The synthesized ligand $(\mathrm{L})$ and its synthesized complexes of $\mathrm{Ni}^{\mathrm{II}}$ and $\mathrm{Cu}^{\mathrm{II}}$ showed significant action against both Aspergillus niger and Penicillium Sp. In the same time, the inhibition zone of synthesized compounds increased against Penicillium with increase in their concentration. 
Table 2. Antimicrobial action of tested compounds against pathogenic microorganism in culture media.

\begin{tabular}{|c|c|c|c|c|c|}
\hline \multirow[t]{2}{*}{ Compound } & \multirow{2}{*}{$\begin{array}{l}\text { Concentration } \\
(\mathrm{mg} / \mathrm{mL})\end{array}$} & \multicolumn{2}{|c|}{ Pathogenic bacteria } & \multicolumn{2}{|c|}{ Pathogenic fungi } \\
\hline & & S. aureus & E. coli & A. niger & Penicillium $s p$ \\
\hline \multirow{3}{*}{ L ligand } & 50 & - & 5 & 12 & 13 \\
\hline & 75 & - & - & 16 & 15 \\
\hline & 100 & - & - & 14 & 17 \\
\hline \multirow{3}{*}{$\begin{array}{c}\mathrm{Ni}^{\mathrm{II}} \\
\text { complex }\end{array}$} & 50 & 4 & 17 & 16 & 13 \\
\hline & 75 & 8 & 17 & 18 & 13 \\
\hline & 100 & - & 17 & 15 & 16 \\
\hline \multirow{3}{*}{$\begin{array}{c}\mathrm{Cu}^{\mathrm{II}} \\
\text { complex }\end{array}$} & 50 & 8 & 10 & 14 & 8 \\
\hline & 75 & 16 & 12 & 15 & 10 \\
\hline & 100 & 16 & 12 & 18 & 17 \\
\hline
\end{tabular}

Values represent zone of inhibition in $\mathrm{mm}$.

\section{CONCLUSION}

In the present work, we have reported the synthesis and characterization of $\mathrm{Ni}^{\mathrm{II}}$ and $\mathrm{Cu}^{\mathrm{II}}$ complexes having general formula $\left[\mathrm{M}(\mathrm{L})_{2} \mathrm{Cl}_{2}\right]$. We have also demonstrated that UV-Vis spectra of azo dye ligand (L) change on altering the $\mathrm{pH}$ values and under irradiation therefore these properties made the synthesized ligand an interesting candidate for its applications in storage device and analytic indicator. Both synthesized complexes of $\mathrm{Ni}^{\mathrm{II}}$ and $\mathrm{Cu}^{\mathrm{II}}$ are nonelectrolyte having tetrahedral environmental and exhibited considerable antibacterial and antifungal activities against both $S$. aureus and E. Coli as well as against A. niger and Penicillium. Sp.

\section{REFERENCES}

1. Kılınçarslan, R.; Erdem, E.; Kocaokutgen, H. Synthesis and spectral characterization of some new azo dyes and their metal complexes. Transition Met. Chem. 2007, 32, 102-106.

2. Abbas, N.; Tirmizi, S.A.; Shabir, G.; Saeed, A.; Hussain, G.; Channer, P.A.; Saleem, R.; Ayaz, M. Chromium(III) complexes of azo dye ligands: Synthesis, characterization, DNA binding and application studies. Inorg. Nano-Met. Chem. 2018, 48, 57-66.

3. Ferreira, G.R.; de Oliveira, L.F. Synthesis, spectroscopic and structural studies of new azo dyes metal chelates derivated from 1-phenyl-azo-2-naphthol. J. Mol. Struct. 2017, 1146, 50 56.

4. Shafeeulla, M.; Krishnamurthy, G.; Bhojynaik, H.S.; Manjuraj, T. Synthesis, cytotoxicity and molecular docking study of complexes containing thiazole moiety. JOTCSA 2017, 4, 787-810.

5. Wang, Y.; Ke, X.; Zhou, X.; Li, J.; Ma, J. Graphene for separation and pre-concentration of trace amounts of cobalt in water samples prior to flame atomic absorption spectrometry. $J$. Saudi. Chem. Soc. 2016, 20, S145-S152.

6. Shokoufi, N.; Shemirani, F.; Assadi, Y. Fiber optic-linear array detection spectrophotometry in combination with dispersive liquid-liquid microextraction for simultaneous preconcentration and determination of palladium and cobalt. Anal. Chim. Acta 2007, 597, 349-356.

7. Cojocariu, C.; Rochon, P. Light-induced motions in azobenzene-containing polymers. Pure Appl. Chem. 2004, 76, 1479-1497. 
8. Coelho, F.L.; de Ávila Braga, C.; Zanotto, G.M.; Gil, E.S.; Campo, L.F.; Gonçalves, P.F. Rodembusch, F.S.; da Silveira Santos, F. Low pH optical sensor based on benzothiazole azo dyes. Sensor Actuat. B-Chem. 2018, 259, 514-525.

9. Coelho, P.J.; Carvalho, L.M.; Moura, J.C. Raposo, M.M. Novel photochromic 2,2'bithiophene azo dyes. Dyes Pigm. 2009, 82, 130-133.

10. Al-Noaimi, M.; Abu-Surrah, A.S.; Tahtamouni, L. Palladium(II) complexes incorporating phenylazo arylmethine ancillary ligands: Synthesis, spectral and antitumor activity. Arab. J. Chem. 2016, 9, S1503-S1509.

11. El-Ghamry, H.A.; Fathalla, S.K.; Gaber, M. Synthesis, structural characterization and molecular modelling of bidentate azo dye metal complexes: DNA interaction to antimicrobial and anticancer activities. Appl. Organomet. Chem. 2018, 32, 1-13.

12. Liu, M.C.; Lin, T.S.; Cory, J.G.; Cory, A.H.; Sartorelli, A.C. Synthesis and biological activity of 3 - and 5-amino derivatives of pyridine-2-carboxaldehyde thiosemicarbazone. $J$. Med. Chem. 1996, 39, 2586-2593.

13. Hamada, Y. Role of pyridines in medicinal chemistry and design of BACE1 inhibitors possessing a pyridine scaffold. Intech Open 2018, 2, 1-19.

14. Patel, N.B.; Shaikh, F.M. Synthesis and antimicrobial activity of new 4-thiazolidinone derivatives containing 2-amino-6-methoxybenzothiazole. Saudi Pharm. J. 2010, 18, 129136.

15. Ohwada, J.; Tsukazaki, M.; Hayase, T.; Oikawa, N.; Isshiki, Y.; Fukuda, H.; Mizuguchi, E.; Sakaitani, M.; Shiratori, Y.; Yamazaki, T.; Ichihara, S. Design, synthesis and antifungal activity of a novel water soluble prodrug of antifungal triazole. Bioorg. Med. Chem. Lett. 2003, 13, 191-196.

16. Watkinson, G. Sulphasalazine: A review of 40 years' experience. Drugs 1986, 32 Suppl 1, $1-11$.

17. Plosker, G.L.; Croom, K.F. Sulfasalazine: A review of its use in the management of rheumatoid arthritis. Drugs 2005, 65, 1825-1849.

18. Gaussian 09, Revision A 02, Gaussian 09 Citation. Gaussian, Inc., Wallingford CT, 2016. Gaussian.com. Available online: https://gaussian.com/g09citation/.

19. Rivera, E.; del Pilar Carreón-Castro, M.; Rodríguez, L.; Cedillo, G.; Fomine, S.; MoralesSaavedra, O.G. Amphiphilic azo-dyes (RED-PEGM). Part 2: Charge transfer complexes, preparation of Langmuir-Blodgett films and optical properties. Dyes Pigm. 2007, 74, 396403.

20. Debnath, D.; Roy, S.; Li, B.H.; Lin, C.H.; Misra, T.K. Synthesis, structure and study of azohydrazone tautomeric equilibrium of 1,3-dimethyl-5-(arylazo)-6-amino-uracil derivatives. Spectrochim. Acta A 2015, 140, 185-197.

21. Rageh, N.M. Tautomeric structures, electronic spectra, acid-base properties of some 7-aryl2,5-diamino-3(4-hydroxyphenyazo)pyrazolo[1,5-a]pyrimidine-6-carbonitriles, and effect of their copper(II) complex solutions on some bacteria and fungi. Spectrochim. Acta A 2004, 60, 1917-1924.

22. Aksungur, T.; Arslan, Ö.; Seferoğlu, N.; Seferoğlu, Z. Photophysical and theoretical studies on newly synthesized N,N-diphenylamine based azo dye. J. Mol. Struct. 2015, 1099, 543550 .

23. Khattab, T.A.; Allam, A.A.; Othman, S.I.; Bin-Jumah, M.; Al-Harbi, H.M.; Fouda, M.M. Synthesis, solvatochromic performance, $\mathrm{pH}$ sensing, dyeing ability, and antimicrobial activity of novel hydrazone. J. Chem. 2018, 2019, 1-10.

24. Beharry, A.A.; Woolley, G.A. Azobenzene photoswitches for biomolecules. Chem. Soc. Rev. 2011, 40, 4422-4437.

25. Amai, N.; Miyasaka, H. Ultrafast dynamics of photochromic systems. Chem. Rev. 2000, 100, 1875-1890. 
26. Merino, E.; Ribagorda, M. Control over molecular motion using the cis-trans photoisomerization of the azo group. Beilstein J. Org. Chem. 2012, 8, 1071-1090.

27. Nicoletta, F.P.; Cupelli, D.; Formoso, P.; De Filpo, G.; Colella, V.; Gugliuzza, A. Light responsive polymer membranes: A review. Membranes 2012, 2, 134-197.

28. Mohammed, H.S. Preparation and characterization of 4-[6-(purinyl)azo]-1-naphthol and some transition metal complexes. Iraq Nat. J. Chem. 2011, 347-360.

29. Alhadi, A.A.; Shaker, S.A.; Yehye, W.A.; Ali, H.M.; Abdullah, M.A. Synthesis, magnetic and spectroscopic studies of $\mathrm{Ni}(\mathrm{II}), \mathrm{Cu}(\mathrm{II}), \mathrm{Zn}(\mathrm{II})$ and $\mathrm{Cd}(\mathrm{II})$ complexes of a newly Schiff base derived from 5-bromo-2-hydroxybezylidene)-3,4,5-trihydroxybenzohydrazide). Bull. Chem. Soc. Ethiop. 2012, 26, 95-101.

30. Sarı, N.; Şahin, S.Ç.; Öğütcü, H.; Dede, Y.; Yalcin, S.; Altundaş, A.; Doğanay, K. Ni(II)tetrahedral complexes: characterization, antimicrobial properties, theoretical studies and a new family of charge-transfer transitions. Spectrochim. Acta Part A: Mol. Biomol. Spectros. 2013, 106, 60-67.

31. Shaker, S.A.; Khaledi, H.; Ali, H.M. Spectroscopic investigations and physico-chemical characterization of newly synthesized mixed-ligand complexes of 2-methylbenzimidazole with metal ions. Chem. Pap. 2011, 65, 299-307.

32. WHO. Antimicrobial resistance in: WHO. http://www.who.int/antimicrobial-resistance/en/.

33. Abou-Dobara, M.I.; El-Sonbati, A.Z.; Diab, M.A.; El-Bindary, A.A.; Morgan, S.M. Thermal properties, antimicrobial activity of azo complexes and ultrastructure study of some affected bacteria. J. Microb. Biochem. Technol. 2014, S3, 1-13.

34. Negm, N.A.; Zaki, M.F. Structural and biological behaviors of some nonionic Schiff-base amphiphiles and their $\mathrm{Cu}(\mathrm{II})$ and $\mathrm{Fe}(\mathrm{III})$ metal complexes. Colloids Surf. B: Bioint. 2008, 64, 179-183.

35. Schattschneider, C.; Kettenmann, S.D.; Hinojosa, S.; Heinrich, J.; Kulak, N. Biological activity of amphiphilic metal complexes. Coord. Chem. Rev. 2019, 385, 191-207. 